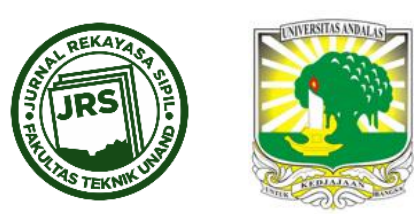

\title{
MOTIVASI PEKERJA PADA PROYEK KONSTRUKSI DI KOTA PADANG
}

\author{
HAFID AZIZ1 ${ }^{\text {, BENNY HIDAYAT }}{ }^{2}$ \\ ${ }^{1} J u r u s a n$ Teknik Sipil Fakultas Teknik Universitas Andalas (ce.hafid@gmail.com) \\ 2Jurusan Teknik Sipil Fakultas Teknik Universitas Andalas (\bennyhidayat@ft.unand.ac.id) \\ Naskah diterima : 22 Desember 2016. Disetujui: 25 Januari 2017. Diterbitkan : 4 Maret 2017
}

\begin{abstract}
ABSTRAK
Ketatnya persaingan yang ada membuat perusahaan kontraktor harus dapat memaksimalkan potensi dan kemampuan yang ada terutama dalam pengelolaan sumber daya manusia. Sementara itu, salah satu sumber daya manusia yang terlibat langsung dalam pelaksanaan proyek konstruksi di lapangan adalah buruh lapangan (craft labour), yang terdiri atas berbagai macam tukang yang memiliki keahlian tertentu yang sering disebut juga sebagai tenaga terampil. Kinerja dari tenaga terampil ini akan dipengaruhi oleh motivasi kerjanya. Motivasi adalah salah satu faktor kunci untuk meningkatkan efektivitas suatu perusahaan. Motivasi sendiri dipengaruhi oleh banyak faktor, diantaranya adalah lingkungan sosial, budaya, dan individu masing-masing orang. Penelitian ini bertujuan untuk mengetahui tingkat kebutuhan yang mempengaruhi motivasi pekerja konstruksi dan menganalisis faktor-faktor motivasi yang mempengaruhi motivasi pekerja konstruksi. Adapun metode yang digunakan adalah dengan cara penyebaran kuisioner kepada seratus orang responden dari beberapa proyek di Kota Padang, serta melakukan wawancara kepada tiga orang pekerja proyek. Berdasarkan hasil penelitian didapatkan 5 faktor yang paling berpengaruh terhadap motivasi pekerja proyek konstruksi di Kota Padang secara umum, yaitu: (1) upah/gaji yang mencukupi, (2) Bonus dan upah tambahan, (3) bayaran yang diterima tepat waktu, (4) Adanya dukungan dari keluarga, (5) Adanya upah lembur.
\end{abstract}

Kata kunci : sumber daya manusia, motivasi, pekerja

\section{PENDAHULUAN}

Ketatnya persaingan yang ada membuat perusahaan kontraktor harus dapat memaksimalkan potensi dan kemampuan yang ada terutama dalam pengelolaan sumber daya manusia. Sementara itu, salah satu sumber daya manusia yang terlibat langsung dalam pelaksanaan proyek konstruksi di lapangan adalah buruh lapangan (craft labour), yang terdiri atas berbagai macam tukang yang memiliki keahlian tertentu yang sering disebut juga sebagai tenaga terampil. Kinerja dari tenaga terampil ini akan dipengaruhi oleh motivasi kerjanya. Dilapangan akan terlihat bahwa kinerja tukang disamping dipengaruhi oleh kondisi kerja yang ada, juga dipengaruhi oleh minat dan dorongan dari diri tukang sendiri. Minat dan dorongan dari dalam diri tukang inilah yang disebut sebagai motivasi kerja. Motivasi adalah salah satu faktor kunci untuk meningkatkan efektivitas suatu perusahaan. 
Motivasi sendiri dipengaruhi oleh banyak faktor, diantaranya adalah lingkungan sosial, budaya, dan individu masing-masing orang. Hal inilah yang menyebabkan tidak adanya suatu standar yang dapat digunakan untuk mengukur dan membandingkan tingkat motivasi antara perusahaan yang satu dengan perusahaan yang lain.

Penelitian ini bertujuan untuk mengetahui tingkat kebutuhan yang mempengaruhi motivasi pekerja konstruksi dan menganalisis faktor-faktor motivasi yang mempengaruhi motivasi pekerja konstruksi. Hasil penelitian diharapkan akan memberikan informasi faktor-faktor apa saja yang dapat memotivasi pekerja konstruksi di Kota Padang, dan juga menambah pemahaman tentang motivasi pekerja, serta dapat dijadikan dasar pertimbangan dalam kelanjutan studi dan penelitian mengenai faktor-faktor motivasi pekerja konstruksi ini.

\section{MOTIVASI KERJA}

Pengertian Motivasi merupakan suatu perubahan yang terjadi pada diri seseorang yang muncul adanya gejala perasaan, kejiwaan dan emosi sehingga mendorong individu untuk melakukan atau bertindak sesuatu yang disebabkan karena kebutuhan, keinginan dan tujuan.

Tabel 1. Faktor Motivasi

\begin{tabular}{|c|c|c|c|c|c|c|c|c|c|c|c|c|c|c|c|c|}
\hline \multirow[b]{2}{*}{ No. } & \multirow[b]{2}{*}{ Faktor Motivasi } & \multicolumn{15}{|c|}{ Sumber } \\
\hline & & 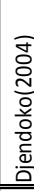 & 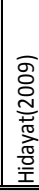 & 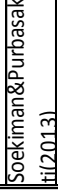 & 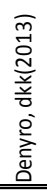 & 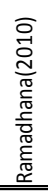 & 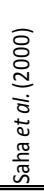 & 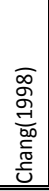 & 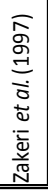 & 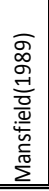 & 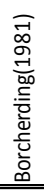 & 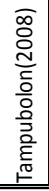 & 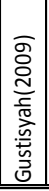 & 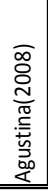 & 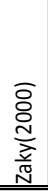 & 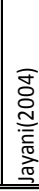 \\
\hline \multicolumn{17}{|c|}{ Physiological Needs } \\
\hline 1 & Upah/gaji yang mencukupi & $\checkmark$ & $\checkmark$ & $\checkmark$ & & $\checkmark$ & $\checkmark$ & $\checkmark$ & $\checkmark$ & $\checkmark$ & $\checkmark$ & $\checkmark$ & $\checkmark$ & $\checkmark$ & $\checkmark$ & $\checkmark$ \\
\hline 2 & Bonus dan upah tambahan & $\checkmark$ & $\checkmark$ & $\checkmark$ & $\checkmark$ & & $\checkmark$ & $\checkmark$ & $\checkmark$ & & & $\checkmark$ & $\checkmark$ & $\checkmark$ & $\checkmark$ & $\checkmark$ \\
\hline 3 & Fasilitas tempat tinggal yang baik & $\checkmark$ & $\checkmark$ & $\checkmark$ & $\checkmark$ & & & & $\checkmark$ & $\checkmark$ & $\checkmark$ & & & & & $\checkmark$ \\
\hline 4 & Adanya pembayaran upah lembur & $\checkmark$ & $\checkmark$ & $\checkmark$ & $\checkmark$ & & $\checkmark$ & $\checkmark$ & $\checkmark$ & $\checkmark$ & $\checkmark$ & & & $\checkmark$ & & \\
\hline 5 & Fasilitas umum yang sudah memadai & & & & $\checkmark$ & & & & & & & & $\checkmark$ & & $\checkmark$ & \\
\hline 6 & Fasilitas pekerjaan yang baik & & & & $\checkmark$ & & & & & & & & $\checkmark$ & & $\checkmark$ & \\
\hline 7 & Bayaran yang diterima tepat waktu & & & & $\checkmark$ & & & & & & & & & & & \\
\hline \multicolumn{17}{|c|}{ Safety \& Security Needs } \\
\hline 8 & Program keselamatan kerja yang baik & $\checkmark$ & $\checkmark$ & $\checkmark$ & $\checkmark$ & $\checkmark$ & $\checkmark$ & $\checkmark$ & $\checkmark$ & $\checkmark$ & $\checkmark$ & & & $\checkmark$ & $\checkmark$ & $\checkmark$ \\
\hline 9 & Pekerjaan yang baik & $\checkmark$ & $\checkmark$ & $\checkmark$ & & & $\checkmark$ & $\checkmark$ & $\checkmark$ & $\checkmark$ & $\checkmark$ & $\checkmark$ & & $\checkmark$ & & \\
\hline 10 & Program kesehatan yang baik & & & $\checkmark$ & & & & & & & & & & & $\checkmark$ & $\checkmark$ \\
\hline \multicolumn{17}{|c|}{ Social Needs } \\
\hline 11 & Hubungan yang baik dengan sesama rekan kerja & $\checkmark$ & $\checkmark$ & $\checkmark$ & $\checkmark$ & $\checkmark$ & $\checkmark$ & $\checkmark$ & $\checkmark$ & $\checkmark$ & $\checkmark$ & $\checkmark$ & & $\checkmark$ & $\checkmark$ & $\checkmark$ \\
\hline 12 & Program pengarahan kerja yang baik & $\checkmark$ & $\checkmark$ & $\checkmark$ & $\checkmark$ & $\checkmark$ & $\checkmark$ & $\checkmark$ & $\checkmark$ & $\checkmark$ & & & & & & \\
\hline 13 & Program pelatihan kerja yang baik & $\checkmark$ & $\checkmark$ & $\checkmark$ & & $\checkmark$ & & & $\checkmark$ & $\checkmark$ & $\checkmark$ & & $\checkmark$ & $\checkmark$ & $\checkmark$ & \\
\hline 14 & Pengawasan kerja yang baik & $\checkmark$ & $\checkmark$ & $\checkmark$ & $\checkmark$ & $\checkmark$ & $\checkmark$ & $\checkmark$ & $\checkmark$ & & & $\checkmark$ & & & $\checkmark$ & \\
\hline 15 & Kondisi lingkungan tempat kerja yang baik & & & $\checkmark$ & & & & & & & & $\checkmark$ & $\checkmark$ & $\checkmark$ & $\checkmark$ & \\
\hline 16 & Adanya dukungan dari keluarga & & & $\checkmark$ & & & & & & & & & & & & \\
\hline \multicolumn{17}{|c|}{ Esteem Needs } \\
\hline 17 & Promosi kenaikan jabatan pekerja yang berprestasi & & & $\checkmark$ & & & & & & & & $\checkmark$ & & $\checkmark$ & & \\
\hline 18 & Pekerjaan yang menantang & $\checkmark$ & $\checkmark$ & $\checkmark$ & $\checkmark$ & $\checkmark$ & $\checkmark$ & $\checkmark$ & $\checkmark$ & & & & & & $\checkmark$ & \\
\hline 19 & Perusahaan memiliki reputasi yang baik & & & $\checkmark$ & & & & & & & & & & & & \\
\hline \multicolumn{17}{|c|}{ Self-Actualization Needs } \\
\hline 20 & Peningkatan kemampuan dan keterampilan kerja & & & & & & & & & & & $\checkmark$ & & & $\checkmark$ & $\checkmark$ \\
\hline 21 & Partisipasi dalam pembuatan keputusan & & & $\checkmark$ & $\checkmark$ & & & & & & & $\checkmark$ & $\checkmark$ & $\checkmark$ & $\checkmark$ & \\
\hline \multicolumn{17}{|c|}{ Others } \\
\hline 22 & Sasaran pekerjaan yang jelas & $\checkmark$ & $\checkmark$ & & $\checkmark$ & & & & $\checkmark$ & & $\checkmark$ & $\checkmark$ & & & & \\
\hline 23 & Pengaturan suplai material yang baik & $\checkmark$ & $\checkmark$ & & & & & & & $\checkmark$ & $\checkmark$ & & & & & $\checkmark$ \\
\hline 24 & Pengaturan jadwal pekerjaan yang baik & $\checkmark$ & $\checkmark$ & & $\checkmark$ & & & & & $\checkmark$ & $\checkmark$ & & & & & \\
\hline 25 & Jarak tempat kerja yang dekat & & & & & $\checkmark$ & & & & & & & & & & \\
\hline 26 & Adanya waktu deadline /batas akhir pekerjaan & & & $\checkmark$ & & & & & & & & & & & & \\
\hline
\end{tabular}

Dalam penelitian tugas akhir ini yaitu mengacu pada teori Abraham Maslow atau disebut juga dengan Teori Hierarki Kebutuhan Maslow. Menurut Maslow, untuk dapat memotivasi 
seseorang, diperlukan pemahaman level keberadaan orang tersebut dalam hirarki kebutuhan dan memusatkan perhatian pada kepuasan kebutuhan pada level tersebut atau level di atasnya. Dalam teori ini dikemukakan bahwa di dalam setiap manusia terdapat sebuah hirarki dari lima kategori kebutuhan, yaitu physiological needs, safety needs, social needs, the need for esteem, dan self-actualization.

Berdasarkan studi literatur didapatkan 26 faktor motivasi yang berasal dari 15 sumber pada penelitian sebelumnya, dimana faktor-faktor motivasi tersebut menjadi acuan dalam membuat pertanyaan kuesioner. Adapun 26 faktor motivasi tersebut dapat dilihat pada Tabel 1.

\section{METODOLOGI PENELITIAN}

Pada penelitian ini akan mencakup teori hirarki kebutuhan Maslow dimana teori-teori dan informasi mengenai faktor-faktor yang mempengaruhi motivasi tersebut dapat ditemukan dari buku, jurnal, artikel laporan penelitian dan situs-situs yang ada diinternet.

Adapun metode pengumpulan data pada penelitian ini yaitu dengan menggunakan Kuesioner dan Wawancara. Kuesioner yang dibuat yaitu terdiri dari pengisian data umum responden dan 26 pertanyaan faktor motivasi dengan menggunakan skala likert, kemudian disebarkan kepada pekerja pada beberapa proyek konstruksi yang ada di Kota Padang sebanyak 100 responden yang terdiri dari beberapa lokasi proyek yaitu pada proyek ruko di daerah Cengkeh, proyek Indarung VI di Semen Padang, proyek gedung perkuliahan di UNP, dan proyek rumah kos-kosan di daerah Limau Manis.

Wawancara pada penelitian ini bertujuan untuk memperkuat hasil yang didapat dari penyebaran kuisioner, sehingga dapat diketahui penjelasan yang lebih jelas mengenai hasil penelitian. Pertanyaan-pertanyaan yang diberikan berpedoman pada hasil pengolahan data kuisioner, yaitu 5 faktor yang paling berpengaruh terhadap motivasi pekerja, wawancara dilakukan pada 3 orang pekerja proyek.

Pengolahan data dilakukan dengan menggunakan Microsoft Excel dan SPSS 20. Dengan menggunakan Microsoft Excel yaitu dikhususkan untuk mencari rata-rata dari setiap jawaban responden, kemudian didapat faktor-faktor yang sangat mempengaruhi motivasi pekerja pada proyek konstruksi di Kota Padang berdasarkan urutan rangking sedangkan SPSS bertujuan untuk mengetahui perbedaan respon dari dua populasi data yang tidak saling berhubungan, yaitu dengan menggunakan uji Mann-Whitney. Adapun uji MannWhitney itu sendiri merupakan bagian dari statistik non-parametrik yang digunakan untuk menguji beda dengan mengggunakan rata-rata variabel dan jumlah data sampel penelitian yang sangat sedikit atau tidak berdistribusi normal, uji Mann-Whitney digunakan untuk menguji satu variabel data kategori dan satu variabel data interval.

\section{ANALISA DAN PEMBAHASAN}

Berikut ini ditampilkan tabel hasil pengolahan data yang digabung dan dikumpulkan dalam satu tabel, dimana yang berisikan rata-rata motivasi pekerja secara umum dan berdasarkan data umum responden, kemudian akan dibahas berdasarkan sub-babnya.

\subsection{Faktor Motivasi Secara Umum}


Tabel 2. Rata-Rata Jawaban Responden

\begin{tabular}{|c|c|c|c|c|c|c|c|c|c|c|c|c|c|c|c|c|c|}
\hline \multirow{2}{*}{ No. } & \multirow{2}{*}{ Faktor Motivasi } & \multirow{2}{*}{ Kode } & \multirow{2}{*}{ Unum } & \multicolumn{3}{|c|}{ Umur } & \multicolumn{2}{|c|}{\begin{tabular}{|c|}
$\begin{array}{c}\text { Status } \\
\text { perkawinan }\end{array}$ \\
\end{tabular}} & \multicolumn{2}{|c|}{ Jumlah Tanggungan } & \multicolumn{3}{|c|}{$\begin{array}{c}\text { Pendidikan } \\
\text { Terakhir }\end{array}$} & \multicolumn{2}{|c|}{$\begin{array}{c}\begin{array}{c}\text { Pengalaman } \\
\text { Bekerja }\end{array} \\
\end{array}$} & \multicolumn{2}{|c|}{\begin{tabular}{|c|} 
Jenis \\
Proyek
\end{tabular}} \\
\hline & & & & $\leq 30$ tahun & \begin{tabular}{|l|}
$31-40$ \\
tahun
\end{tabular} & $\geq 40$ tahun & Kawin & \begin{tabular}{|l|} 
Belum \\
Kawin \\
\end{tabular} & \begin{tabular}{|c|} 
Tidak Ada \\
T anggungan \\
\end{tabular} & $\begin{array}{c}\text { Ada } \\
T \text { anggungan } \\
\end{array}$ & $\mathrm{SD}$ & SMP & $\geq \mathrm{SMA}$ & $\leq 15$ tahun & $>15$ tahun & Besar & r Kecil \\
\hline 1 & Upah/gaji yang mencukupi & $\mathrm{Q} 8$ & 4,54 & 4,56 & 4,53 & 3,90 & 4,55 & 4,52 & 4,57 & 4,53 & 4,56 & 4,65 & 4,51 & 4,55 & 4,50 & 4,55 & 5,52 \\
\hline 2 & Bonus dan upah tambahan & Q9 & 4,40 & 4,63 & 4,24 & 4,00 & 4,39 & 4,43 & 4,43 & 4,39 & 4,22 & 4,59 & 4,38 & 4,41 & 4,33 & 4,47 & 4,2 \\
\hline 3 & Fasilitas tempat tinggal yang baik & Q10 & 3,93 & 4,15 & 3,74 & 3,51 & 3,90 & 4,04 & 4,14 & 3,87 & 3,78 & 3,59 & 4,03 & 3,93 & 3,92 & 4,00 & 3,72 \\
\hline 4 & Adanya pembayaran upah lembur & Q11 & 4,00 & 4,33 & 3,74 & 3,82 & 3,95 & 4,17 & 4,14 & 3,96 & 4,00 & 3,76 & 4,05 & 4,01 & 3,92 & 4,03 & 3,92 \\
\hline 5 & Fasilitas umum yang sudah memadai & Q12 & 3,79 & 3,85 & 3,85 & 3,18 & 3,79 & 3,78 & 3,95 & 3,75 & 3,44 & 3,47 & 3,91 & 3,77 & 3,92 & 3,77 & 3,84 \\
\hline 6 & Fasilitas pekerjaan yang baik & Q13 & 3,85 & 3,89 & 3,85 & 3,41 & 3,86 & 3,83 & 3,81 & 3,86 & 3,78 & 3,82 & 3,86 & 3,86 & 3,75 & 3,91 & 3,68 \\
\hline 7 & Bayaran yang diterima tepat waktu & Q14 & 4,29 & 4,33 & 4,21 & 3,90 & 4,26 & 4,39 & 4,38 & 4,27 & 4,11 & 4,41 & 4,28 & 4,30 & 4,25 & 4,33 & 4,16 \\
\hline 8 & Program keselamatan kerja yang baik & Q15 & 3,95 & 4,04 & 3,94 & 3,46 & 3,92 & 4,04 & 4,05 & 3,92 & 3,78 & 4,00 & 3,96 & 3,98 & 3,75 & 4,03 & 3,72 \\
\hline 9 & Pekerjaan yang baik & Q16 & 3,62 &, 78 & 3,59 & 18 & 3,58 & 3,74 & 3,71 & 3,59 & 3,00 & 3,53 & 3,72 & 3,60 & 3,75 & 3,79 & 3,12 \\
\hline 10 & Program kesehatan yang baik & Q17 & 3,82 & 3,70 & 3,79 & 3,41 & 3,82 & 3,83 & 3,86 & 3,81 & 3,22 & 3,82 & 3,89 & 3,83 & 3,75 & 3,92 & 3,52 \\
\hline 11 & Hubungan yang baik dengan sesama rekan kerja & Q18 & 3,54 & 3,67 & 3,50 & 3,15 & 3,51 & 3,65 & 3,67 & 3,51 & 3,78 & 3,76 & 3,46 & 3,55 & 3,50 & 3,51 & 3,64 \\
\hline 12 & Program pengarahan kerja yang baik & Q19 & 3,41 & 3,33 & 3,50 & 2,92 & 3,44 & 3,30 & 3,38 & 3,42 & 3,44 & 3,47 & 3,39 & 3,40 & 3,50 & 3,32 & 3,68 \\
\hline 13 & Program pelatihan kerja yang baik & Q20 & 3,61 & 3,48 & 3,68 & 3,28 & 3,64 & 3,52 & 3,57 & 3,62 & 3,56 & 3,65 & 3,61 & 3,66 & 3,25 & 3,67 & 3,44 \\
\hline 14 & Pengawasan kerja yang baik & Q21 & 3,43 & 3,37 & 3,50 & 2,95 & 3,45 & 3,35 & 3,38 & 3,44 & 3,11 & 3,82 & 3,38 & 3,44 & 3,33 & 3,52 & 3,16 \\
\hline 15 & Kondisi lingkungan tempat kerja yang baik & Q22 & 3,91 & 4,00 & 3,88 & 3,41 & 3,94 & 3,83 & 3,86 & 3,92 & 3,44 & 4,24 & 3,89 & 3,94 & 3,67 & 3,99 & 3,68 \\
\hline 16 & Adanya dukungan dari keluarga & Q23 & 4,09 & 4,07 & 3,97 & 3,72 & 4,03 & 4,30 & 4,33 & 4,03 & 4,11 & 3,71 & 4,18 & 4,09 & 4,08 & 4,09 & 4,08 \\
\hline 17 & Promosi kenaikan jabatan pekerja yang berprestasi & Q24 & 3,53 & 3,19 & 3,65 & 3,18 & 3,60 & 3,30 & 3,29 & 3,59 & 3,56 & 3,76 & 3,47 & 3,53 & 3,50 & 3,69 & 3,04 \\
\hline 18 & Pekerjaan yang menantang & Q25 & 3,18 & 2,96 & 3,18 & 2,85 & 3,22 & 3,04 & 3,10 & 3,20 & 2,89 & 3,29 & 3,19 & 3,18 & 3,17 & 3,39 & 2,56 \\
\hline 19 & Perusahaan memiliki reputasi yang baik & Q26 & 3,43 & 3,56 & 3,41 & 3,10 & 3,43 & 3,43 & 3,43 & 3,43 & 3,33 & 3,59 & 3,41 & 3,43 & 3,42 & 3,55 & 3,08 \\
\hline 20 & Peningkatan kemampuan dan keterampilan kerja & Q27 & 3,50 & 3,48 & 3,68 & 3,08 & 3,47 & 3,61 & 3,62 & 3,47 & 3,11 & 3,41 & 3,57 & 3,56 & 3,08 & 3,59 & 3,2 \\
\hline 21 & Partisipasi dalam pembuatan keputusan & Q28 & 3,53 & 3,30 & 3,59 & 3,21 & 3,58 & 3,35 & 3,33 & 3,58 & 3,11 & 3,71 & 3,54 & 3,52 & 3,58 & 3,63 & 3,24 \\
\hline 22 & Sasaran pekerjaan yang jelas & Q29 & 3,77 & 3,59 & 3,88 & 3,36 & 3,77 & 3,78 & 3,81 & 3,76 & 4,33 & 3,82 & 3,69 & 3,75 & 3,92 & 3,71 & 3,96 \\
\hline 23 & Pengaturan suplai material yang baik & Q30 & 3,67 & 3,41 & 3,82 & 3,21 & 3,74 & 3,43 & 3,48 & 3,72 & 3,67 & 3,94 & 3,61 & 3,68 & 3,58 & 3,65 & 3,72 \\
\hline 24 & Pengaturan jadwal pekerjaan yang baik & Q31 & 3,67 & 3,44 & 3,74 & 3,26 & 3,71 & 3,52 & 3,52 & 3,71 & 3,67 & 3,88 & 3,62 & 3,69 & 3,50 & 3,76 & $5,3,4$ \\
\hline 25 & Jarak tempat kerja yang dekat & Q32 & 3,34 & 3,11 & 3,41 & 2,82 & 3,43 & 3,04 & 3,14 & 3,39 & 3,22 & 3,82 & 3,24 & 3,30 & 3,67 & 3,33 & 3,36 \\
\hline 26 & Adanya waktu deadline /batas akhir pekerjaan & Q33 & 3,38 & 3,41 & 3,44 & 2,90 & 3,35 & 3,48 & 3,48 & 3,35 & 2,78 & 3,53 & 3,42 & 3,34 & 3,67 & 3,47 & 7. 3,12 \\
\hline
\end{tabular}

Pada subbab ini akan dibahas tentang faktor-faktor yang mempengaruhi motivasi pekerja di Kota Padang secara umum yang didapat dari 100 responden. Hasil pengolahan data dapat dilihat pada Tabel 2. Rata-Rata Jawaban Respondendiatas. Hasil dari pengolahan data tersebut juga ditampilkan dalam bentuk diagram dan dapat dilihat pada Gambar 1 berikut.

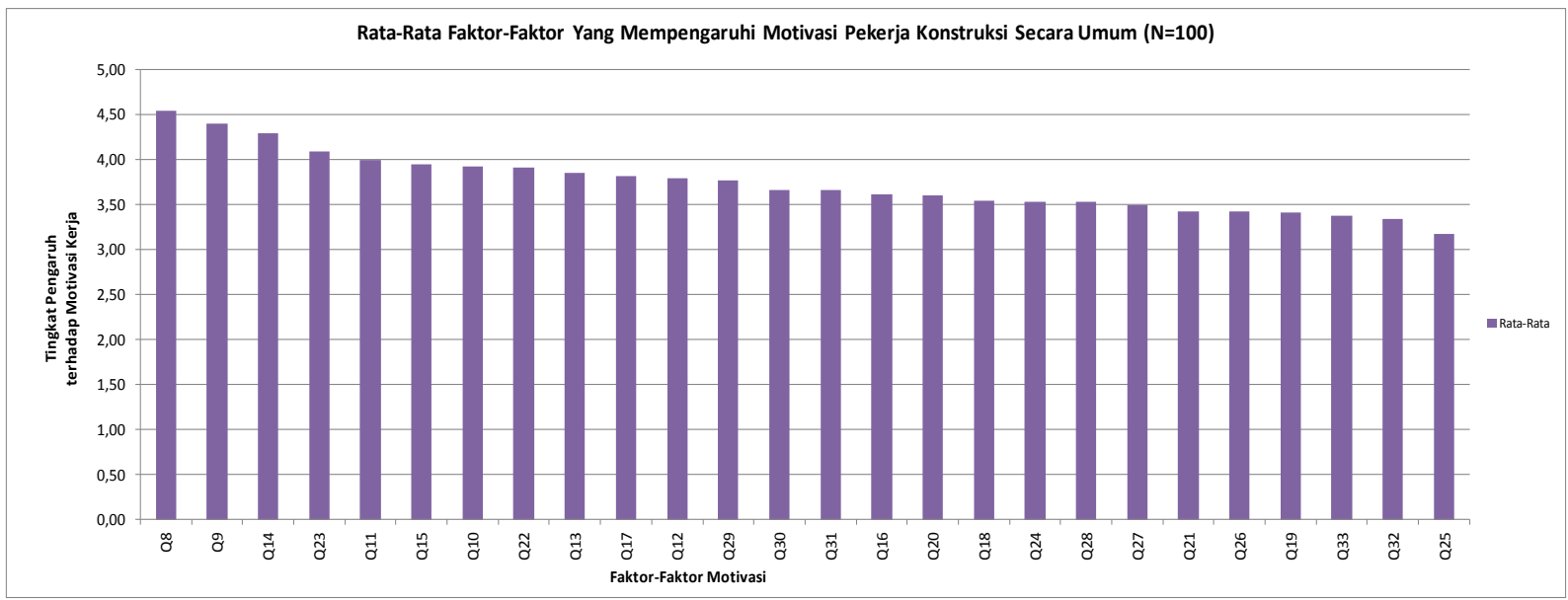

Gambar 1. Grafik Rata-Rata Faktor-Faktor Yang Mempengaruhi Motivasi Pekerja Secara Umum

Pada Tabel 2 dan Gambar 1 menunjukkan faktor motivasi berdasarkan nilai rata-rata tertinggi sampai yang terendah. Selanjutnya akan dibahas 5 faktor motivasi yang tertinggi, adapun faktor-faktornya yaitu sebagai berikut:

1. Upah atau Gaji yang Mencukupi

Berdasarkan Tabel 2 urutan tertinggi yaitu upah atau gaji yang mencukupi dengan nilai ratarata tertinggi sebesar 4,54. Dari 100 responden terdapat 55 responden yang menjawab 
"Sangat Berpengaruh" yang menyatakan bahwa upah/gaji yang mencukupi merupakan faktor yang sangat berpengaruh terhadap motivasi pekerja, dan 44 responden lainnya menjawab "Berpengaruh" yang menyatakan bahwa upah/gaji yang mencukupi memiliki tingkat berpengaruh terhadap motivasi pekerja, kemudian terdapat 1 responden yang menjawab "Kurang Berpengaruh". Tidak ada responden yang menjawab "Tidak Berpengaruh" dan "Sangat Tidak Berpengaruh" upah atau gaji yang mencukupi terhadap motivasi pekerja. Dari hasil wawancara, narasumber 2 berpendapat bahwa upah terhadap motivasi kerja pengaruhnya sensitif sekali, mengenai berapa jumlahnya, karena dengan upah yang cukup dapat digunakan untuk kebutuhan sebagaimana mestinya.

\section{Bonus dan Upah Tambahan}

Urutan kedua dari faktor motivasi tertinggi yaitu Bonus dan Upah Tambahan, karena dari 100 responden diantaranya sebanyak 48 responden menjawab "Sangat Berpengaruh" Bonus dan Upah tambahan terhadap motivasi pekerja, kemudian 47 responden menjawab "Berpengaruh" bonus dan upah Tambahan terhadap motivasi pekerja. Hanya 3 responden yang menjawab "Kurang Berpengaruh" bonus dan upah Tambahan terhadap motivasi pekerja, selanjutnya 2 responden yang menjawab "Tidak Berpengaruh" bonus dan upah tambahan terhadap motivasi pekerja dan tidak ada responden yang menjawab "Sangat Tidak Berpengaruh". Adapun nilai rata-rata dari bonus dan upah tambahan tersebut dapat dilihat pada Tabel 4.1 yaitu sebesar 4,40, dapat diartikan bahwa responden lebih banyak menjawab "Sangat Berpengaruh". Maka bonus dan upah tambahan ini merupakan faktor yang sangat berpengaruh terhadap motivasi pekerja konstruksi. Seringkali pendapatan yang diterima para pekerja konstruksi tidak mengimbangi kebutuhan mereka sehari-hari, oleh karena itu untuk mengatasi hal tersebut mereka menginginkan bonus untuk menambah pendapatan mereka (Hidayat, 2009).

\section{Bayaran yang Diterima Tepat Waktu}

Dari total keseluruhan responden sebanyak 36 responden mempunyai pendapat bahwa bayaran yang diterima tepat waktu "Sangat Berpengaruh" terhadap motivasi pekerja, kemudian sebanyak 57 responden mempunyai pendapat bayaran yang diterima tepat waktu "Berpengaruh" terhadap motivasi pekerja dan sebanyak 7 responden mempunyai pendapat bayaran yang diterima tepat waktu "Kurang Berpengaruh" terhadap motivasi pekerja. Tidak ada responden yang mempunyai pendapat bayaran yang diterima tepat waktu "Tidak Berpengaruh" dan "Sangat Tidak Berpengaruh" terhadap motivasi pekerja. Berdasarkan jawaban responden tersebut didapat nilai rata-rata bayaran yang diterima tepat waktu sebesar 4,29, sehingga dapat disimpulkan bahwa bayaran yang diterima tepat waktu merupakan faktor yang sangat berpengaruh terhadapa motivasi pekerja. Selain upah yang mencukupi, bayaran yang mereka terima juga harus terjadwal dengan baik Seperti yang dikatakan Martin (2007) bahwa gaji dan upah yang terima oleh pekerja harus diberikan tepat pada waktunya karena apabila tidak sesuai dengan waktunya maka akan menimbulkan rasa tidak puas dan kemarahan para pekerja, hal ini akan berpengaruh pada berkurangnya produktifitas kerja.

\section{Adanya Dukungan dari Keluarga}

Pada faktor motivasi adanya dukungan dari keluarga ini terdapat 28 responden berpendapat adanya dukungan dari keluarga "Sangat Berpengaruh" terhadap motivasi kerja mereka, kemudian 56 responden yang berpendapat adanya dukungan dari keluarga "Berpengaruh" terhadap motivasi kerja, seterusnya 13 responden yang berpendapat adanya dukungan dari keluarga "Kurang Berpengaruh" terhadap motivasi kerja dan 3 responden berpendapat 
adanya dukungan dari keluarga "Tidak Berpengaruh" terhadap motivasi kerja. Tidak ada responden yang berpendapat "Sangat Tidak Berpengaruh". Dari jawaban responden tersebut dapat dilihat bahwa responden lebih cenderung menjawab dengan alternatif jawaban "Berpengaruh" dan menghasilkan nilai rata-rata sebesar 4,09, sehingga berdasarkan interval dapat disimpulkan bahwa faktor motivasi adanya dukungan dari keluarga ini mempunyai level "Berpengaruh" terhadap motivasi pekerja konstruksi. Dari wawancara Narasumber 3 mengatakan dukungan dari keluarga itu harus ada, kalau adanya dukungan dari keluarga kita bisa semangat dalam bekerja seperti dengan adanya komunikasi rutin dengan keluarga.

\section{Adanya Pembayaran Upah Lembur}

Dari hasil pengolahan data pada Tabel 2 dapat dilihat yaitu terdapat 28 responden yang memilih jawaban "Sangat Berpengaruh" pada faktor motivasi adanya upah lembur, 53 responden yang memilih jawaban "Berpengaruh" pada faktor motivasi adanya upah lembur. Selanjutnya 10 responden yang memilih jawaban "Kurang Berpengaruh" pada faktor motivasi adanya upah lembur dan 9 responden yang memilih jawaban "Tidak Berpengaruh" pada faktor motivasi adanya upah lembur serta tidak ada responden yang menjawab "Sangat Tidak Berpengaruh" pada faktor motivasi adanya upah lembur. Pada faktor motivasi adanya upah lembur ini mempumyai urutan kelima tertinggi seperti yang ditunjukkan pada Tabel 2 karena kecenderungan responden yang menjawab dengan alternatif jawaban "Berpengaruh" dan memiliki nilai rata-rata sebesar 4,00. Ini dapat diartikan adanya upah lembur mempunyai tingkatan "Berpengaruh" terhadap motivasi pekerja konstruksi. Lembur (overtime) adalah suatu cara yang biasa ditempuh oleh pekerja untuk mendapatkan upah tambahan dengan jam kerja yang lebih banyak dari biasanya. Namun dengan beberapa pertimbangan bahwa dengan bekerja lembur tentunya akan mengeluarkan banyak tenaga dan jam istirahat akan berkurang sehingga hal ini menyebabkan menurunnya produktifitas pekerja tersebut pada pekerjaan selanjutnya (Djendoko, 2004). Akan tetapi dalam segi kebutuhan, semangat dan keinginan setiap para pekerja berbeda-beda maka tak heran lembur terkadang merupakan cara yang harus dilakukan untuk mendapatkan pendapatan yang lebih.

\subsection{Analisa Faktor Motivasi Berdasarkan Tingkat Kebutuhan}

Adapun hasil analisanya yaitu dimana hasil analisis menunjukkan bahwa Physiological Needs (Kebutuhan Fisik) menduduki peringkat pertama dengan nilai rata-rata sebesar 4,11, peringkat kedua diduduki oleh Safety \& Security Needs (Kebutuhan Keamanan dan Keselamatan) dengan nilai rata-rata sebesar 3,80, dan peringkat ketiga yaitu diduduki oleh Social Needs (Kebutuhan Sosial) dengan nilai rata-rata sebesar 3,67, peringkat selanjutnya adalah Esteem Needs (Kebutuhan akan Penghargaan), dan Self-Actualization Needs (Kebutuhan akan Jati Diri) pada peringkat keempat dan kelima dengan nilai rata-rata masing-masing sebesar 3,38 dan 1,50. Dimana bentuk grafiknya yaitu yang ditunjukkan pada Gambar 2.

Pada Gambar 2 tersebut juga dapat dilihat bahwa peringkat faktor kebutuhan tersebut sesuai dengan teori kebutuhan Maslow, dimana kebutuhan fisik masih menjadi kebutuhan utama para pekerja konstruksi, setelah kebutuhan fisik ini terpenuhi maka barulah diikuti dengan kebutuhan lainnya seperti kebutuhan keamanan \& keselamatan, kebutuhan sosial, kebutuhan akan penghargaan dan yang terakhir kebutuhan akan jati diri. 


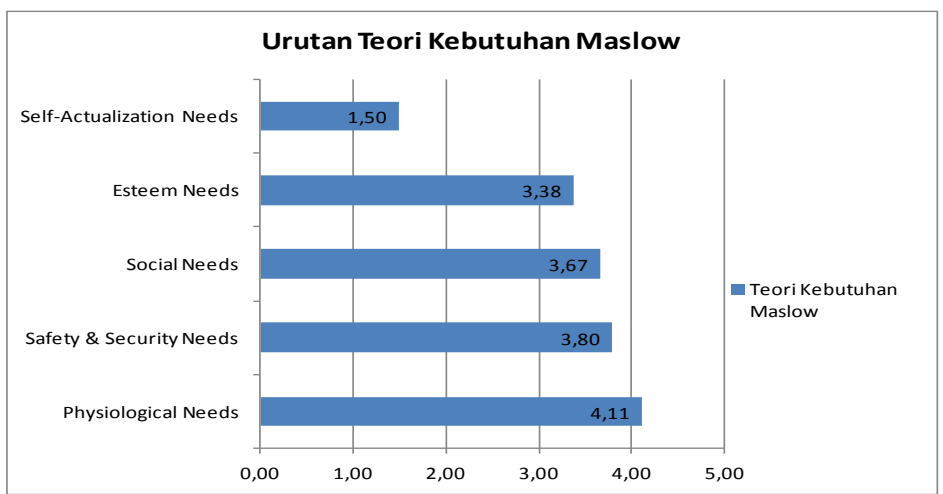

Gambar 2. Peringkat Teori Kebutuhan Maslow

\subsection{Faktor-Faktor yang Mempengaruhi Motivasi Pekerja Berdasarkan Data Umum Responden}

Semua hasil pengolahan data berdasarkan data umum responden ini ditunjukkan pada Tabel 2 diatas dan uji statistiknya dengan metode non-parametrik pada Tabel 3.

Pada metode non-parametrik ini digunakan uji Mann-Whitney, yang bertujuan untuk mengetahui apakah terdapat perbedaan respon dari 2 populasi data yang saling independen (tidak berkaitan).

Hipotesis penelitian ini terdiri dari:

HO = Kedua populasi identik (motivasi kedua kelompok tidak berbeda secara signifikan);

H1 = Kedua populasi tidak identik atau berbeda (motivasi kedua kelompok memang berbeda secara signifikan).

Tabel 3. Nilai Probabilitas Uji Non-Parametrik

\begin{tabular}{|c|c|c|c|c|c|c|c|c|c|c|c|c|}
\hline \multirow{2}{*}{ No. } & \multirow{2}{*}{ Faktor Motivasi } & \multirow{2}{*}{ Kode } & \multicolumn{3}{|c|}{ Umur } & \multirow{2}{*}{\begin{tabular}{|c|}
$\begin{array}{c}\text { Status } \\
\text { perkawinan }\end{array}$ \\
$\begin{array}{c}\text { Kawin \& } \\
\text { Belum Kawin }\end{array}$ \\
\end{tabular}} & \multirow{2}{*}{\begin{tabular}{|c|}
$\begin{array}{c}\text { Jumlah } \\
\text { Tanggungan }\end{array}$ \\
$\begin{array}{c}\text { Tidak Ada Tanggungan } \\
\text { \& Ada T Tanggungan }\end{array}$ \\
\end{tabular}} & \multicolumn{3}{|c|}{ Pendidikan Terakhir } & \multirow{2}{*}{$\begin{array}{c}\begin{array}{c}\text { Pengalaman } \\
\text { Bekerja }\end{array} \\
\leq 15 \text { tahun \& } \\
>15 \text { tahun } \\
\end{array}$} & \multirow{2}{*}{\begin{tabular}{|c|} 
Jenis \\
Proyek \\
Besar \& \\
Kecil \\
\end{tabular}} \\
\hline & & & \begin{tabular}{|c|}
30 tahun \& \\
$31-40$ tahun
\end{tabular} & \begin{tabular}{|c|}
$\leq 30$ tahun $\&$ \\
$\geq 40$ tahun \\
\end{tabular} & \begin{tabular}{|l|}
$31-40$ tahun \\
$\& \geq 40$ tahun \\
\end{tabular} & & & SD \& SMP & $\mid \mathrm{SD} \& \geq \mathrm{SMA}$ & SMP \& $\geq$ SMA & & \\
\hline 1 & Upah/gaji yang mencukupi & Q8 & 0,940 & 0,817 & 0,876 & 0,798 & 0,792 & 0,923 & 0,578 & 0,322 & 0,741 & 0,967 \\
\hline 2 & Bonus dan upah tambahan & Q9 & 0,024 & 0,150 & 0,396 & 0,857 & 0,819 & 0,310 & 0,817 & 0,182 & 1,000 & 0,289 \\
\hline 3 & Fasilitas tempat tinggal yang baik & Q10 & 0,018 & 0,311 & 0,226 & 0,413 & 0,202 & 0,496 & 0,435 & 0,052 & 0,977 & 0,191 \\
\hline 4 & Adanya pembayaran upah lembur & Q11 & 0,003 & 0,146 & 0,127 & 0,333 & 0,480 & 0,565 & 0,981 & 0,309 & 0,670 & 0,684 \\
\hline 5 & Fasilitas umum yang sudah memadai & Q12 & 0,652 & 0,240 & 0,362 & 0,610 & 0,205 & 0,701 & 0,079 & 0,153 & 0,835 & 0,734 \\
\hline 6 & Fasilitas pekerjaan yang baik & Q13 & 0,712 & 0,686 & 0,984 & 0,970 & 0,900 & 0,727 & 0,560 & 0,991 & 0,640 & 0,163 \\
\hline 7 & Bayaran yang diterima tepat waktu & Q14 & 0,341 & 0,941 & 0,268 & 0,352 & 0,428 & 0,331 & 0,517 & 0,460 & 0,809 & 0,227 \\
\hline 8 & Program keselamatan kerja yang baik & Q15 & 0,534 & 0,335 & 0,713 & 0,412 & 0,402 & 0,588 & 0,570 & 0,958 & 0,343 & 0,128 \\
\hline 9 & Pekerjaan yang baik & Q16 & 0,225 & 0,153 & 0,883 & 0,288 & 0,390 & 0,144 & 0,014 & 0,640 & 0,578 & 0,002 \\
\hline 10 & Program kesehatan yang baik & Q17 & 0,438 & 0,254 & 0,710 & 0,966 & 0,745 & 0,137 & 0,034 & 0,564 & 0,753 & 0,072 \\
\hline 11 & Hubungan yang baik dengan sesama rekan kerja & Q18 & 0,557 & 0,328 & 0,718 & 0,548 & 0,496 & 0,853 & 0,152 & 0,109 & 0,717 & 0,499 \\
\hline 12 & Program pengarahan kerja yang baik & Q19 & 0,552 & 0,897 & 0,608 & 0,600 & 0,968 & 0,978 & 0,844 & 0,835 & 0,738 & 0,098 \\
\hline 13 & Program pelatihan kerja yang baik & Q20 & 0,597 & 0,765 & 0,793 & 0,913 & 0,689 & 0,731 & 0,686 & 0,859 & 0,096 & 0,310 \\
\hline 14 & Pengawasan kerja yang baik & Q21 & 0,644 & 0,950 & 0,677 & 0,681 & 0,815 & 0,105 & 0,419 & 0,127 & 0,576 & 0,135 \\
\hline 15 & Kondisi lingkungan tempat kerja yang baik & Q22 & 0,694 & 0,483 & 0,844 & 0,631 & 0,846 & 0,030 & 0,139 & 0,184 & 0,180 & 0,262 \\
\hline 16 & Adanya dukungan dari keluarga & Q23 & 0,916 & 0,336 & 0,334 & 0,134 & 0,097 & 0,252 & 0,776 & 0,019 & 0,859 & 0,749 \\
\hline 17 & Promosi kenaikan jabatan pekerja yang berprestasi & Q24 & 0,047 & 0,043 & 0,942 & 0,239 & 0,242 & 0,686 & 0,797 & 0,267 & 0,878 & 0,002 \\
\hline 18 & Pekerjaan yang menantang & Q25 & 0,439 & 0,260 & 0,706 & 0,486 & 0,675 & 0,438 & 0,473 & 0,745 & 0,996 & 0,001 \\
\hline 19 & Perusahaan memiliki reputasi yang baik & Q26 & 0,485 & 0,432 & 0,947 & 0,903 & 0,896 & 0,671 & 0,988 & 0,482 & 0,875 & 0,032 \\
\hline 20 & Peningkatan kemampuan dan keterampilan kerja & Q27 & 0,540 & 0,333 & 0,073 & 0,301 & 0,281 & 0,458 & 0,132 & 0,331 & 0,130 & 0,148 \\
\hline 21 & Partisipasi dalam pembuatan keputusan & Q28 & 0,163 & 0,120 & 1,000 & 0,227 & 0,229 & 0,109 & 0,139 & 0,593 & 0,982 & 0,061 \\
\hline 22 & Sasaran pekerjaan yang jelas & Q29 & 0,242 & 0,450 & 0,704 & 0,970 & 0,833 & 0,069 & 0,024 & 0,645 & 0,700 & 0,156 \\
\hline 23 & Pengaturan suplai material yang baik & Q30 & 0,140 & 0,222 & 0,790 & 0,240 & 0,465 & 0,425 & 0,937 & 0,214 & 0,941 & 0,528 \\
\hline 24 & Pengaturan jadwal pekerjaan yang baik & Q31 & 0,401 & 0,328 & 0,895 & 0,650 & 0,749 & 0,491 & 0,943 & 0,320 & 0,442 & 0,134 \\
\hline 25 & Jarak tempat kerja yang dekat & Q32 & 0,383 & 0,334 & 0,944 & 0,234 & 0,469 & 0,161 & 0,832 & 0,065 & 0,269 & 0,967 \\
\hline 26 & Adanya waktu deadline /batas akhir pe & Q33 & 0,886 & 0,716 & 0,605 & 0,652 & 0,666 & 0,062 & 0,077 & 0,898 & 0,293 & \\
\hline
\end{tabular}




\subsubsection{Motivasi Pekerja Berdasarkan Umur Responden}

Dalam pembahasannya responden ini dibagi menjadi kelompok responden umur $\leq 30$ tahun, 31-40 tahun, dan $\geq 40$ tahun. Pada Tabel 3 dapat dilihat yang mana pada kelompok umur responden dibawah 30 tahun dan diatas 40 tahun yang menjadi peringkat pertama yaitu bonus dan upah tambahan dengan nilai rata-rata masing-masing 4,63 dan 4,00 dengan selisihnya sebesar 0,63, dimana semakin besar selisihnya semakin penting faktor tersebut untuk meningkatkan motivasi pekerja. Untuk analisa pada kelompok umur 31-40 tahun peringkat pertama didominasi oleh upah/gaji yang mencukupi dengan rata-rata 4,53, untuk peringkat selanjutnya dan data selengkapnya dapat dilihat pada Tabel 4.1 diatas. Dari Tabel 4.1 tersebut ditampilkan juga grafiknya pada Gambar 3 berikut.

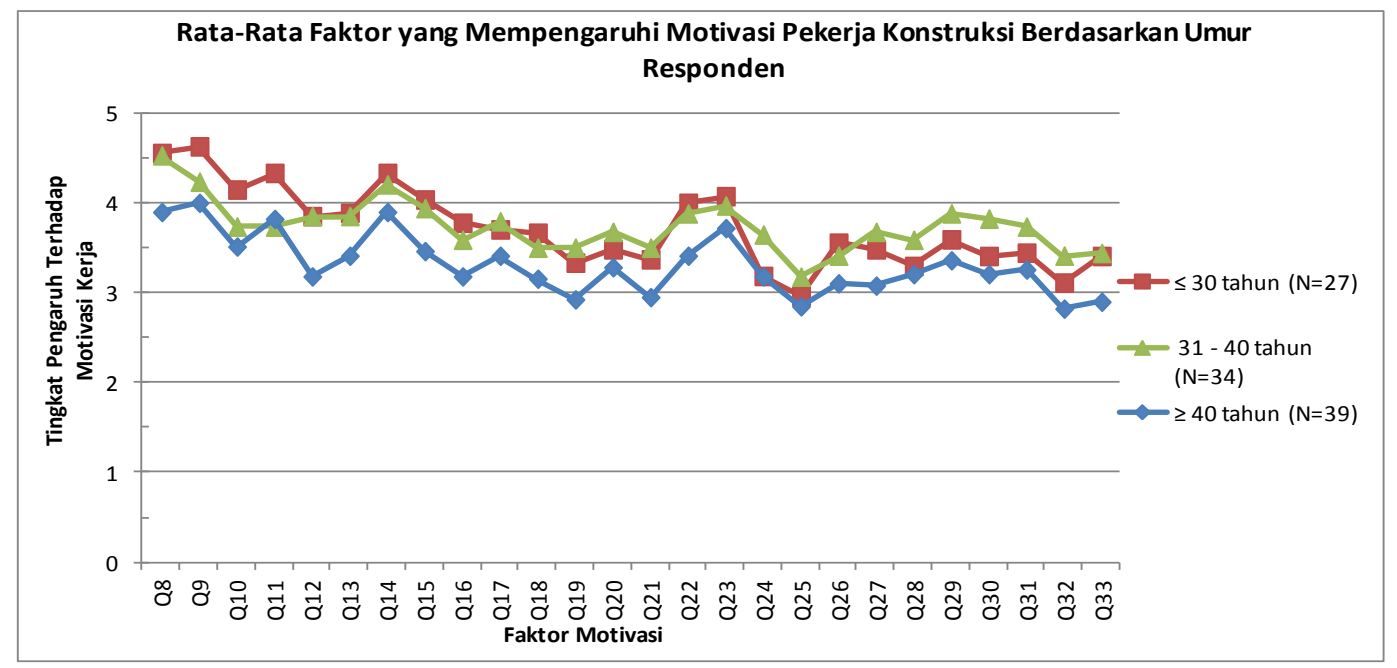

Gambar 3. Grafik Faktor Motivasi Berdasarkan Umur Responden

Kemudian dilakukan uji statistik dengan metoda Mann-Whitney, karena pada uji MannWhitney ini hanya menguji pada 2 kelompok data, maka ketiga data tersebut akan di uji secara bergantian. Hasil dapat dilihat pada Tabel 3

- Responden umur $\leq 30$ tahun dan umur 31-40 tahun

Dari Tabel tersebut terlihat Q9, Q10, Q11, dan Q24 pada kolom Asymp.Sig. (2tailed)/significance memiliki nilai < 0,05, maka HO ditolak. Ini menyatakan bahwa motivasi kedua kelompok umur responden ini memang berbeda secara signifikan.

- Responden umur $\leq 30$ tahun dan umur $\geq 40$ tahun

Pada kelompok umur responden ini semua item sudah menunjukkan nilai Asymp. Sig (2-tailed) > 0,05, ini berarti hipotesis Ho diterima, yang menyatakan bahwa kelompok umur responden umur ini tidak memiliki perbedaan motivasi secara signifikan, kecuali pada Q24 = promosi kenaikan jabatan pekerja yang berprestasi karena memiliki nilai $<0,05$.

- Responden umur 31-40 tahun dan umur $\geq 40$ tahun 
Tidak terdapat perbedaan motivasi dari kelompok responden ini karena dari seluruh item-item motivasi semua memiliki probabilitas > 0,05 yang berarti $\mathrm{HO}$ diterima dan $\mathrm{H} 1$ ditolak.

\subsubsection{Motivasi Pekerja Berdasarkan Status Perkawinan}

Dari Tabel 3 terlihat pada status reponden yang sudah kawin dan status responden yang belum kawin memiliki kesamaan pada peringkat (1) faktor motivasi upah atau gaji yang mencukupi dengan rata-rata masing-masing 4,55 dan 4,52 dengan selisih 0,02, kemudian (2) faktor motivasi bonus dan upah tambahan dengan rata-rata masing-masing 4,39 dan 4,43 dengan selisih 0,05 , dan (3) yaitu faktor motivasi bayaran yang diterima tepat waktu dengan rata-rata masing-masing 4,26 dan 4,39 dengan selisih 0,13. Nilai selisihnya menyatakan semakin tinggi nilai selisihnya semakin penting faktor tersebut untuk meningkatkan motivasi pekerja. Dapat diartikan bahwa tidak ada perbedaan faktor yang mempengaruhi motivasi pekerja berdasarkan status perkawinan ini. Bentuk grafiknya pada gambar berikut.

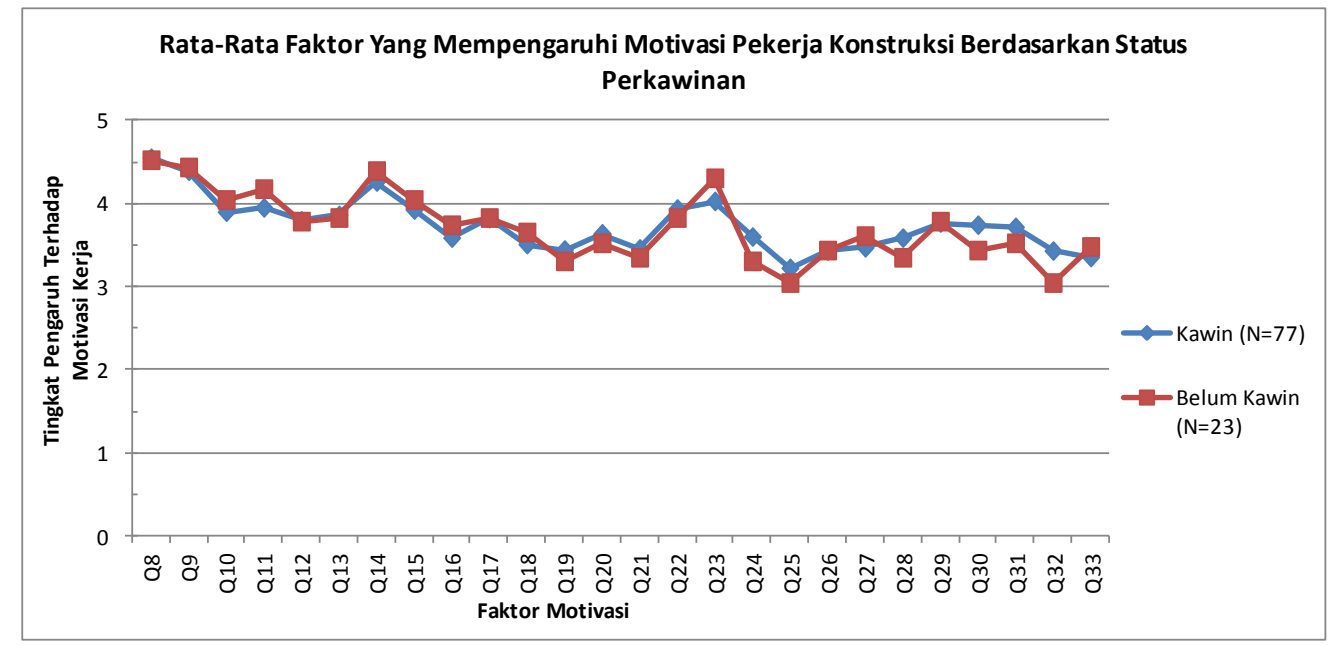

Gambar 4. Grafik Faktor Motivasi Berdasarkan Status Perkawinan

Dari uji statisitik kelompok status perkawinan yaitu kawin dan belum kawin dengan faktor motivasi yang berpengaruh yang ditunjukkan pada Tabel 3, dimana semua faktor motivasi memiliki nilai probabilitas diatas 0,05 , ini menyatakan bahwa kelompok status perkawinan ini memiliki kesamaan terhadap motivasi kerja dan hipotesis Ho diterima.

\subsubsection{Motivasi Pekerja Berdasarkan Jumlah Tanggungan}

Dari Tabel 2 telah ditunjukkan bahwa antara responden yang tidak mempunyai tanggungan dan responden yang mempunyai tanggungan juga memiliki kesamaan pada 3 peringkat tertinggi faktor motivasi pekerja konstruksi yaitu (1) upah/gaji yang mencukupi dengan ratarata masing-masing sebesar 4,57 dan 4,53 selisihnya 0,04; (2) bonus dan upah tambahan dengan besarnya rata-rata masing-masing 4,43 dan 4,39 selisihnya 0,04; dan (3) bayaran yang diterima tepat waktu dengan rata-rata masing-masing sebesar 4,38 dan 4,27 selisihnya 0,12, dimana semakin tinggi selisihnya semakin penting faktor tersebut untuk meningkatkan motivasi pekerja pada kelompok responden berdasarkan jumlah tanggungan ini. Bentuk grafik dari data tersebut ditunjukkan pada Gambar 5 dibawah ini. 


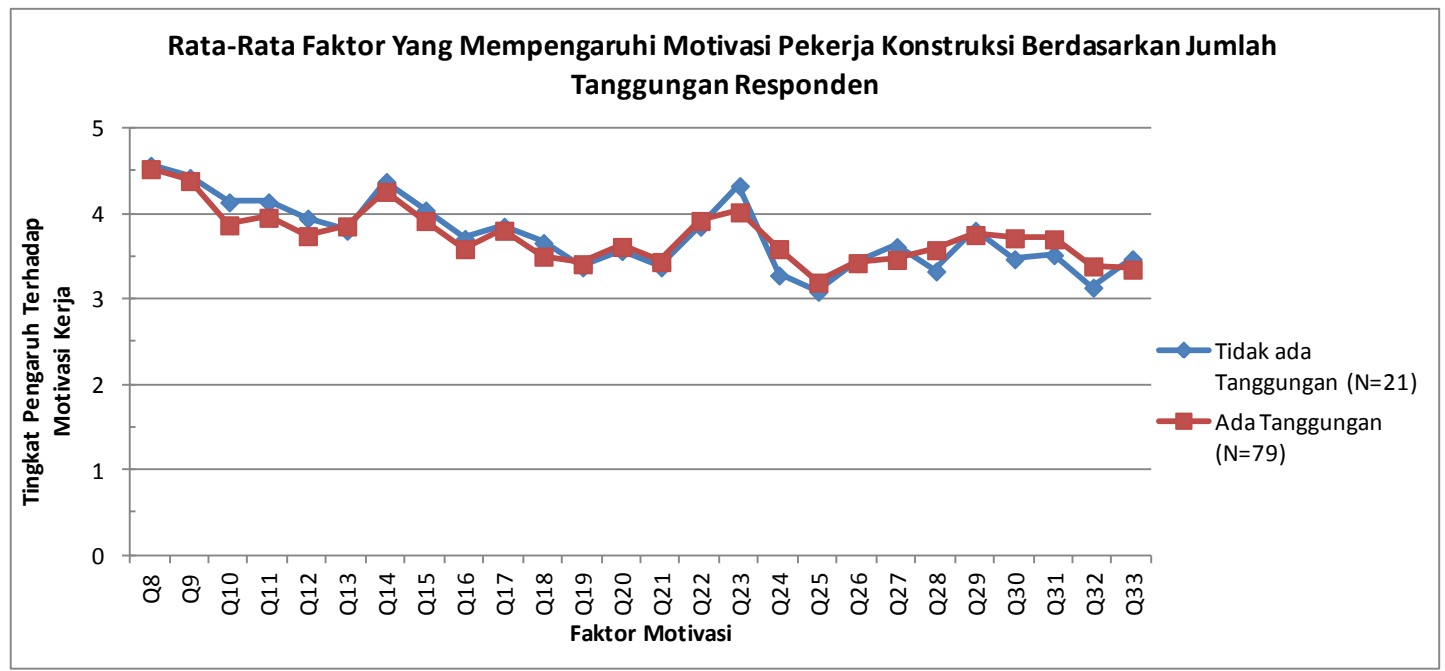

Gambar 5. Grafik Faktor Motivasi Berdasarkan Jumlah Tanggungan

Data yang akan diuji statistiknya terdiri dari yang mempunyai tanggungan dan yang tidak mempunyai tanggungan, dimana pada hasil pengujian tidak ada perbedaan dari motivasi yang berpengaruh karena semua probabilitas berada diatas 0,05 dan Ho diterima. Dimana hasil pengujian selengkapnya terdapat pada Tabel 3 diatas.

\subsubsection{Motivasi Pekerja Berdasarkan Pendidikan Terakhir}

Berdasarkan hasil olahan datanya untuk responden berpendidikan terakhir SD yang menjadi 3 peringkat tertinggi yaitu (1) upah/gaji yang mencukupi dengan rata-rata 4,56; (2) sasaran pekerjaan yang jelas dengan rata-rata 4,33; (3) bonus dan upah tambahan dengan rata-rata 4,22. Kemudian untuk responden yang berpendidikan terakhir SMP dan responden yang berpendidikan terakhir SMA maupun diatas SMA keduanya memiliki kesamaan dalam 3 peringkat tertinggi untuk faktor motivasi yaitu (1) upah/gaji yang mencukupi dengan rata-rata masing-masing sebesar 4,65 dan 4,51 selisihnya 0,13 ; (2) bonus dan upah tambahan dengan rata-rata masing-masing 4,59 dan 4,38 selisihnya 0,21; dan (3) bayaran yang diterima tepat waktu yaitu dengan rata-ratanya masing-masing 4,41 dan 4,28 selisihnya 0,13. Dimana semakin tinggi nilai selisihnya semakin penting faktor tersebut untuk meningkatkan motivasi. Berdasarkan Tabel 2 tersebut ditampilkan juga bentuk grafiknya yang ditunjukkan pada Gambar 6 berikut.

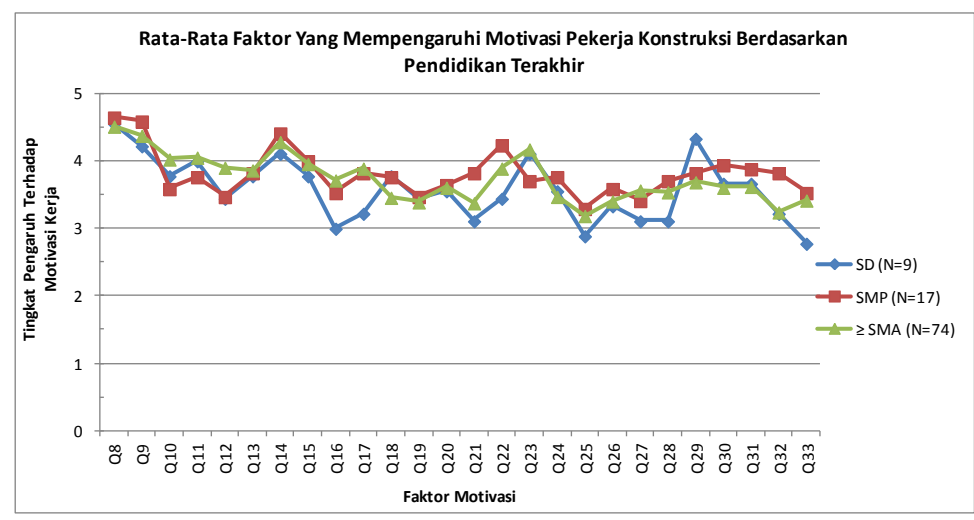

Gambar 6. Grafik Faktor Motivasi Berdasarkan Pendidikan Terakhir 
Pada kelompok pendidikan terakhir ini terbagi menjadi kelompok pendidikan terakhir SD, SMP dan SMA. Karena terdapat 3 variabel maka akan diuji secara bergantian.

\section{- Pendidikan Terakhir SD dan SMP}

Pada kelompok responden ini setelah dilakukan pengujian semua item faktor motivasi memiliki probabilitas > 0,05, namun pada Q22 = kondisi lingkungan tempat kerja yang baik memiliki nilai probabilitas sebesar 0,03 $<0,05$ ditunjukkan pada Tabel 4.3 yang berarti hanya pada item motivasi ini terdapat perbedaan diantara keduanya. Dapat dikatakan Ho ditolak dan H1 diterima.

- Pendidikan Terakhir SD dan $\geq$ SMA

Hasil pengolahan data dari penelitian ini didapatkan hanya item Q16, Q17, Q29 yang dinyatakan Ho ditolak karena memiliki probabilitas kecil dari 0,05, yang diartikan bahwa hanya pada ketiga item tersebut memiliki perbedaan pada kelompok pendidikan terakhir ini, namun untuk item lainnya tidak ada perbedaan.

- Pendidikan Terakhir SMP dan $\geq$ SMA

Hasil output pada Tabel 3 dari pengolahan data didapatkan bahwa semua faktor motivasi probabilitas sudah berada diatas 0,05, namun hanya pada Q23 = pengaturan suplai material yang baik yang memiliki nilai kecil 0,05, dapat dikatakan bahwa faktor motivasi Q23 memiliki perbedaan secara signifikan dan dinyatakan Ho ditolak.

\subsubsection{Motivasi Pekerja Berdasarkan Pengalaman Bekerja}

Berdasarkan pengalaman bekerja ini, yaitu responden yang memiliki pengalaman kerja dibawah 15 tahun dan responden yang memiliki pengalaman kerja diatas 15 tahun. Setelah dianalisa tidak terdapat perbedaan dari 3 peringkat tertinggi faktor motivasi yang berpengaruh dari 2 pengelompokkan responden tersebut seperti yang ditunjukkan pada Tabel 2 diatas. Adapun yang menjadi peringkat pertama dengan rata-rata masing-masing 4,55 dan 4,50 $(0,05)$ masih pada upah/gaji yang mencukupi, kemudian yang menduduki peringkat kedua dengan rata-rata dari masing-masing 4,41 dan 4,33(0,08) pada bonus dan upah tambahan dan pada peringkat ketiga dengan rata-rata 4,30 dan 4,25(0,05) yaitu bayaran yang diterima tepat waktu. Apabila semakin tinggi nilai selisih semakin penting faktor tersebut untuk meningkatkan motivasi pekerja. Adapun bentuk grafiknya dari subbahasan ini, yaitu: 


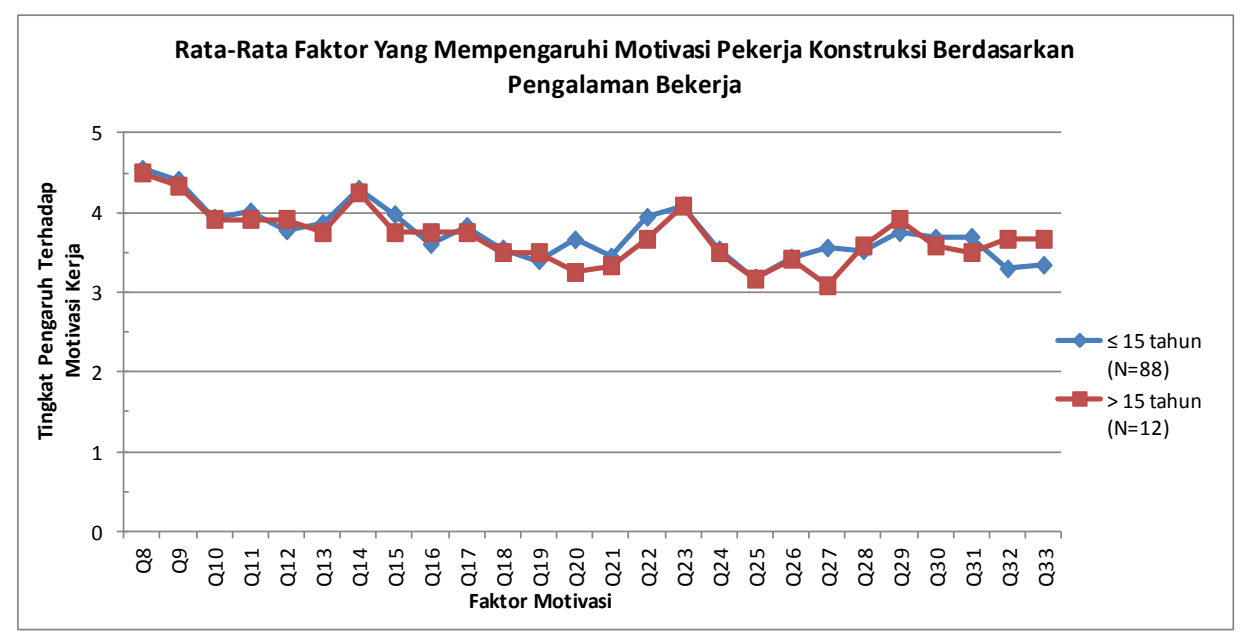

Gambar 7. Grafik Faktor Motivasi Berdasarkan Pengalaman Bekerja

Pada kelompok responden dibedakan ini pada responden memiliki pengalaman bekerja selama $\leq 15$ tahun dan $>15$ tahun, dimana dari pengolahan data dari keduanya pada Tabel 3 didapatkan bahwa nilai Asymp. Sig (2-tailed) pada semua item motivasi > 0,05 dan Ho diterima, ini dapatkan dikatakan bahwa keduanya memiliki kesamaan dan tidak terdapat perbedaan secara signifikan.

\subsubsection{Motivasi Pekerja Berdasarkan Jenis Proyek}

Pada Tabel 2 diatas dapat dilihat tidak ada perbedaan yang signifikan karena 3 peringkat faktor motivasi tertinggi baik responden yang bekerja pada proyek besar dan responden yang bekerja pada proyek kecil hanya saja dibedakan pada besarnya nilai rata-rata. Adapun yang menempati peringkat pertama yang mempunyai rata-rata masing-masing 4,55 dan $4,52(0,03)$ yaitu upah/gaji yang mencukupi, kemudian yang menempati peringkat kedua dengan rata-rata masing-masing sebesar 4,47 dan $4,20(0,27)$ yaitu bonus dan upah tambahan dan pada peringkat ketiga dengan rata-rata 4,33 dan 4,16(0,17) ditempati oleh bayaran yang diterima tepat waktu. Selisih nilai tersebut menyatakan bahwa dimana semakin tinggi nilai selisihnya semakin penting faktor tersebut untuk meningkatkan motivasi pekerja.

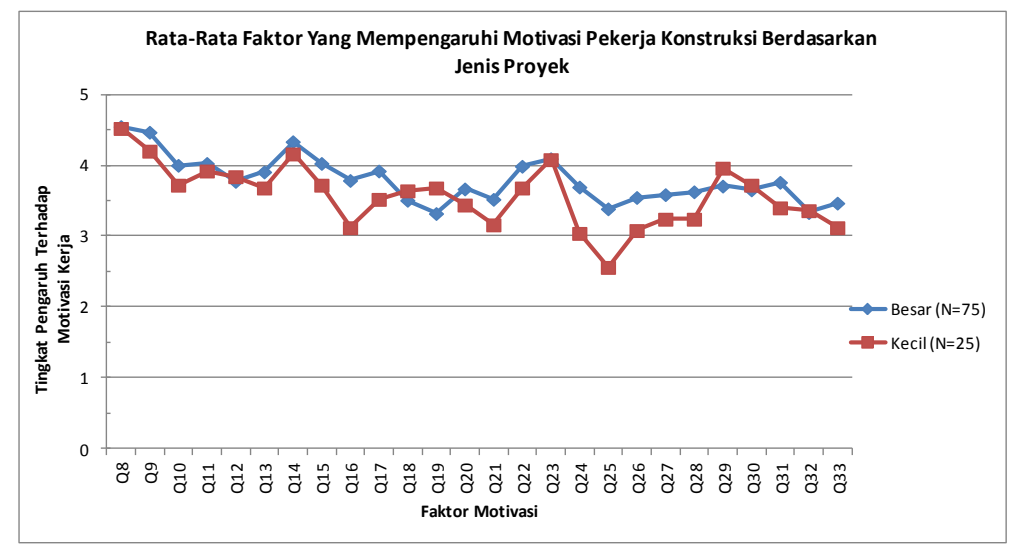

Gambar 8. Grafik Faktor Motivasi Berdasarkan Jenis Proyek 
Terdapat dua pembagian dari jenis proyek ini yaitu besar dan kecil yang akan diuji dengan sampel faktor motivasi, dimana hasilnya menunjukkan bahwa nilai Asym. Sig (2-tailed) dari Q16, Q24, dan Q25 < 0,05 dan dinyatakan Ho ditolak, H1 diterima. Ini menandakan bahwa terdapat perbedaan secara signifikan dari kedua jenis proyek ini untuk ketiga faktor motivasi tersebut, akan tetapi untuk faktor motivasi lainnya tidak terdapat perbedaan secara signifikan karena nilai Asym. Sig (2-tailed) melebihi dari 0,05.

\section{KESIMPULAN DAN SARAN}

Berdasarkan penelitian yang telah dilakukan dapat diambil kesimpulan sebagai berikut:

1. Dari 26 faktor motivasi terdapat 5 faktor yang paling berpengaruh terhadap motivasi pekerja proyek konstruksi di Kota Padang secara umum, yaitu: (1) upah/gaji yang mencukupi, (2) Bonus dan upah tambahan, (3) bayaran yang diterima tepat waktu, (4) Adanya dukungan dari keluarga, (5) Adanya upah lembur.

2. Secara umum para pekerja proyek konstruksi di Kota Padang masih berada pada tingkat physiological needs, secara khusus pada sub-faktor upah/gaji yang mencukupi.

3. Tingkat kebutuhan pekerja proyek konstruksi di Kota Padang masih sesuai dengan teori kebutuhan yang dikemukakan oleh Maslow dimana kebutuhan Physiological Needs (Kebutuhan Fisik) menduduki peringkat pertama, peringkat kedua diduduki oleh Safety \& Security Needs (Kebutuhan Keamanan dan Keselamatan), dan peringkat ketiga yaitu diduduki oleh Social Needs (Kebutuhan Sosial), peringkat selanjutnya adalah Esteem Needs (Kebutuhan akan Penghargaan), dan Self-Actualization Needs (Kebutuhan akan Jati Diri) pada peringkat keempat dan kelima.

4. Dari hasil uji non-parametrik hanya pada kelompok umur responden, pendidikan terakhir, dan jenis proyek terdapat perbedaan motivasi secara signifikan.

Adapun saran yang dapat diberikan dari penelitian ini yaitu:

1. Penelitian ini diharapkan bisa menjadi acuan untuk penelitian selanjutnya khususnya terkait tentang motivasi pekerja proyek konstruksi.

2. Dengan penelitian ini diharapkan pada pihak proyek konstruksi hendaknya melakukan pengukuran tingkat motivasi pekerja konstruksi secara berkala agar proyek dapat terus memantau kinerja pekerja konstruksi karena ini juga berhubungan pada produktifitas pekerja dan pencapaian tujuan proyek.

3. Pada penelitian selanjutnya disarankan agar dapat melakukan penelitian pada skala yang lebih kecil seperti dengan studi kasus pada satu proyek saja, sehingga dapat diteliti kembali tentang motivasi ini tidak hanya pada pekerja namun juga pada semua jabatan atau jenjang keahlian pada proyek konstruksi.

\section{DAFTAR KEPUSTAKAAN}

Asnawi, S. 2002. Teori Motivasi Dalam Pendekatan Psikologi Industri dan Organisasi, Studia Press.

Asisi Dody, F. 2012. Studi Mengenai Hubungan Motivasi Kerja Dan Waktu Kerja Tukang Pada Proyek Konstruksi. Tugas Akhir S1, Universitas Atma Jaya Yogyakarta.

Denyro, dkk. 2013. Model Pengukuran Tingkat Motivasi Dan Demotivasi Pekerja Proyek Konstruksi Di Surabaya. Tugas Akhir S1, Universitas Kristen Petra Surabaya.

Djendoko, Dwi. 2004. Motivasi Pekerja Pada Beberapa Proyek Konstruksi Di Surabaya. Jurnal Civil Engineering Dimension, Vol. 6, No. 2, 80-87, September 2004 
Farlen, Frans. 2011. Pengaruh Motivasi Kerja Dan Kemampuan Kerja Terhadap Kinerja Karyawan. Tugas Akhir S1, Universitas Pembangunan Nasional "Veteran" Yogyakarta.

Hidayat, F. 2009. Motivasi Pekerja Pada Proyek Konstruksi di Kota Bandung. Media Teknik Sipil, Vol. 9, No. 1, 57-70, Januari 2009

Kaming, P.F. Olomolaiye, P. O., Holt, G.D., Harris, F. C., Factors Influencing Craftmen's Productivity in Indonesia, International Journal of Project Management, 15(1), 21-30.

Martin, V. 2007. Pengaruh Kompensasi Finansial Terhadap Motivasi Kerja. Skripsi, Universitas Widyatma Bandung.

Martoyo, Susilo. 2007. Manajemen Sumber Daya Manusia, BPFE Yogyakarta.

Rante, Israel. 2009. Faktor motivasi dan demotivasi pekerja pada beberapa Proyek konstruksi di yogyakarta. Tugas Akhir S1, Universitas Atma Jaya Yogyakarta.

Renatha, Olivia. 2015. Motivasi Kerja Pegawai Pada Pelayanan Pembuatan Paspor Di Kantor Imigrasi Kelas I Makassar. Skripsi, Universitas Hasanuddin Makassar.

Soekiman dan Purbasakti. 2013. Faktor-Faktor Yang Mempengaruhi Motivasi Kerja Pekerja Terampil Di Industri Konstruksi. Tugas Akhir S1, Universitas Katolik Parahyangan Bandung.

Biro Pusat Statistik 2013, http://www.bps.go.id (diakses pada tanggal 13 September 2015)

Silviana, Intan. Kuesioner Penelitian. 20 Mei 2015. http://ime351.weblog.esaunggul.ac.id/ (diakses pada tanggal 22 September 2015) 